\title{
An UNACKNOWLEDGEd AdVERSARY: CARL SCHMitT, JosePH SCHUMPETER, AND THE Classical DOCTRINe OF DEMOCRACY
}

\author{
JanaLee Cherneski, \\ Oriel College, University of Oxford \\ janalee.cherneski@gmail.com
}

WORKING PAPER, JULY 2013

UNDER FINAL REVISION FOR PUBLICATION

*Please do not cite or circulate without permission from the author*

\begin{abstract}
"Seeing things similar and making things the same is the sign of weak eyes."

Friedrich Nietzsche 1887

The Gay Science

“... this merely shows how far we have travelled from the old moorings

of liberal democracy. To exalt national unity into a moral precept spells acceptance of one of the most important principles of fascism."
\end{abstract}

Joseph Schumpeter, 1942

\begin{abstract}
:
This paper suggests a new answer to an old question by arguing that there is an intellectual source for the Classical Doctrine of democracy that Joseph Schumpeter critiques in Capitalism, Socialism and

Democracy. Contrary to the established scholarly view that Schumpeter simply attacked a straw man, and that there was no actual intellectual source for the doctrine Schumpeter described as Classical, this paper draws on intellectual history to suggest that Schumpeter drew the Classical Doctrine from a very real source: Carl Schmitt's fascist theory of democracy. Comparing the structure of the analytical arguments of these two thinkers, this paper then considers the important political differences of two thinkers, and the implications their historical debate has on the way we, as citizens and as scholars, think about political thinking, the way we practice (and speak about) democracy, and what is at stake in the way we conceive concepts such as democracy and the political.
\end{abstract}




\section{Introduction}

Joseph Schumpeter's definition of democracy as "that institutional arrangement for arriving at political decisions in which individuals acquire the power to decide by means of a competitive struggle for the people's vote" has been one of the most cited defintions of democracy by social scientists (Schumpeter 1942: 269; Schmitter and Karl 1996: 61n3; Ricci 1970: 240). Within political theory it has also been one of the most criticized theories of democracy, condemned for harbouring an anti-democratic elitism that is said to abandon the ideals of participation and representation (Bachrach 1967: 1725; Brito Viera and Runciman 2008: 58; Gottlieb 1959; Held 2006: 143-144; Lichtman 1969: 205; Mackie 2009; März 1991: 19-31; Medearis 2001: 115, 121-122; Posner 2003: 183; Runciman 2007; Scheureman 1999: 200; Shapiro and Hacker- Cordón 1999: 4); and often criticized for reducing democracy to a sterile electoral method that was ethically void of "the distinctive moral function of democratic politics and government" (Davis 1964: 37; Walker 1966; Soutphommassane 2011). It may be fair to criticize Schumpeter, as many have done, for offering an un-historicized and under-contextualized definition of democracy. Yet ironically a misleading impression of Schumpeter's work occurs when his thought is abstracted from the particular contexts (the Habsburg Dynasty and the Weimar Republic) and the particular historical circumstances (the intensification of antiSemitism and the emergence of fascism) that gave rise to it. ${ }^{1}$ Although Capitalism, Socialism and Democracy appeared in English after Schumpeter had immigrated to the United States, and although its most explicit engagements were with contemporary utilitarian thought (as befits an economist), in this paper I suggest that one of Schumpeter's hidden interlocutors is Carl Schmitt, with whom he worked at Bonn. My

\footnotetext{
${ }^{1}$ This paper only focuses on Schumpeter's Weimar period.
} 
argument here is that Schumpeter's intervention appears in quite a new light when we read it in relation to Schmitt's work of the 1920s, work with which Schumpeter was quite familiar. Once one makes this connection Schumpeter begins to appear as a defender of liberal democracy rather than as an advocate for authoritarianism.

In the following paper, I consider some of Schumpeter's political, historical, and intellectual contexts, particulalry in relation to a set of concerns shared by a group of central-European émigré intelligentsia. After examining conventional criticisms of Schumpeter within the history of ideas, I propose Schmitt's work as the intellectual source for Schumpeter's Classical Doctrine of democracy. I advance this argument by demonstrating how Schumpeter mirrors, but inverts, Schmitt's argument; I then strengthen my claim by examining letters and other historical evidence which proves there was a decisive intellectual and personal connection between Schumpeter and Schmitt. After considering how this connection has been treated by the few current scholars who touch on it, I proceed to show how Schmitt's fascist theory of democracy dismissed liberal values via democratic rhetoric - whereas Schumpeter, rejecting Schmitt, sought to preserve the union of democracy with moral and political liberalism, even as he thought economic liberalism would give way to socialism. Thus, this argument provides new evidence for reading Schumpeter as a political liberal and demonstrates the distinct moral boundary that differentiates liberalism, and the practice of liberal democracy, from fascism.

\section{Schumpeter in the History of (Anglo-American) Political Thought}

To advance his definition of democracy in Captialism, Socialism and Democracy Schumpeter writes against something he calls the "Classical Doctrine" of Democracy. He 
defines the Classical Doctrine as "that institutional arrangement for arriving at political decisions which realizes the common good," whereby the common good is based on an "exactly coterminous" Common Will, and whereby the Common Will is therefore understood as a political and moral agreement shared - "by all reasonable individuals"about the content of the common good (1942: 250-252). This paper will not answer all the critical debates that arise in relation to Schumpeter's argument about the common good, but rather will contribute to thinking about the intellectual history and social philosophy that informed how Schumpeter thought about that concept.

When scholars examine Schumpeter's definition from within the history of ideas they often accuse Schumpeter of knocking down a straw man. Indeed, the conventionally accepted scholarly position is that the Classical Doctrine Schumpeter describes is unrepresentative of any existing intellectual theory of democracy (Wolfe 1943: 267; Pateman 1970: 17; Miller 1983: 136-137; Medearis 2001: 114-115). As Plamenatz put it, Schumpeter does not merely attack "a dead horse, but one that was never alive" (1973: 96). And thus Plamenatz insisted Schumpeter's theory of the Classical Doctrine is "ignorant and inept" and that "it is uncertain whom [Schumpeter] is attacking, and even what beliefs he is ascribing to them" (1973: 96).

More sensitive readers of Schumpeter such as David Miller suggest the Classical Doctrine attacked by Schumpeter is an "unwieldy composite of Enlightenment rationalism, utilitarianism and Rousseauian ideas" (1983: 137). Nevertheless Miller's view, then, still sets up a strawn-man, albeit a sophisticated one, by arguing that the views Schumpeter attributed to the classical doctrine neither occurred in any existing intellectual theory of democracy, nor accurately reflected popular beliefs and common 
(mis)conceptions about how democracy functioned. For Miller, and others, the acceptance of the straw-man argument is the gateway that leads to a host of normative and ideological critiques. In particular, scholars on the left suggest Schumpeter intended to include all of liberal ideology — as well as the idea of "individual human agency," on which humanism the liberal discourse of human rights is often based-among the values and views subject to his attack. (Held 2008: 180; Lichtman 1969: 198; Mackie 2008; Medearis 2001, 2009; Ricci 1970: 246-253; Santoro 1993: 121-122; Scheuerman 1999).

Miller's note that the Classical Doctrine is a composite that functions as a proxy is, for the most part, correct. There is, in fact, a blurry composite of views and intellectual targets wrapped together in Schumpeter's discussion. However, in this paper I will make the case for a new answer to this old question about Schumpeter's intellectual sources by suggesting that Carl Schmitt be included in the list of intellectual sources for the Classical Doctrine. If my argument holds, then scholars may need to re-consider precisely which values and views Schumpeter purportedly attacked, and why he did so.

\section{Schmitt as Schumpeter's Unacknowledged Source}

A brief foray into German intellectual history reveals that Schumpeter was not the first to invoke Rousseauian ideas as a proxy for an argument about democracy. In 1926, Carl Schmitt invoked a particular interpretation of Rousseau's theory of democracy — which at one point he even called the "classical definition" — to justify a fascist political theory (1926: 14). To understand this claim and why, for the purposes of 
this paper, I am reading the theory Schmitt presents as fascist, some brief background context is necessary. ${ }^{2}$ In Die geistesgeschichtliche Lage des heutigen Parlamentarismus ${ }^{3}$ (first published in 1923), Schmitt attacked the ideals of open public discussion embedded in liberal parliamentarism on the grounds that they were out-dated ideals of $19^{\text {th }}$-century liberalism that were no longer realistic or useful under the conditions of modern mass democracy (Schmitt 1923a: 32, 49). What is significant about Schmitt's critique of political liberalism is that it was clothed in the rhetoric of democratic realism. Indeed, Schmitt used the phenomenon of democratic expansion, and the social facts associated with mass democracy in Europe, to suggest a factual description of circumstances in which Germany's liberal parliamentary structure had been hollowed of its core values.

The core of German liberalism coalesced around the values and the parliamentary political structure Schmitt attacked, so naturally German liberals took Schmitt to task for the illiberal implications embedded in his critique. (Döring 1983: 7; Herf 1984: 6, 28, 51; Mommsen 1974: 173; Schmitt 1928: 327). For example, the much-celebrated legal philosopher Hans Kelsen accused Schmitt of taking an "absolutist view" of public deliberation that misrepresented, and was incompatible with, liberal realism (Kelson 1926: 39-40). ${ }^{4}$ Similarly Richard Thoma, a liberal legal scholar and the man who, in Peter Caldwell's words, "produced the most coherent political theory of the Weimar constitutional system," also took issue with Schmitt's claims against parliament

\footnotetext{
${ }^{2}$ For the purposes of this paper my interpretion falls in line with those who take Schmitt to be representative of fascism, including Caldwell 2008; Dyzenhaus 1996, 1997a, 1997b; McCormick 2004; Scheuerman 1993, 1995, 1996. That said, my argument is not affected by those who might wish to argue that Schmitt simply clarified the weaknesses with the German liberal theory of his day (and Weimar's constitution) without following through on the fascist turn suggested by his description. Either way, my argument holds, for I simply suggest Schumpeter responded to the intellectual theory of democracy described in Schmitt's work.

${ }^{3}$ Known in English as The Crisis of Parliamentary Democracy, a better translation of the title is "The intellectual historical context of today's parliamentarism."

${ }^{4}$ For an overview of the debates between Kelsen and Schmitt see Dyzenhaus 1997a: 102-160.
} 
(Caldwell 2000: 151). Thoma outlined his concerns about the dangerous, illiberal implications of Schmitt's anti-parliamentary alternatives in a detailed response to Schmitt entitled “Zur Ideologie des Parlamentarismus und der Diktatur” (Thoma 1925). ${ }^{5}$

Schmitt did not capitulate to the moral arguments of his liberal critics; in fact he did quite the opposite. In an article titled "On the Contradiction between Parliamentarism and Democracy," written and published in 1926 — and then included as a new preface to the republished Crisis of Parliamentary Democracy — Schmitt replied to Thoma by outlining the principles behind his project and invoking Rousseau to intellectually legitimate an illiberal, and fascist, theory of democracy. The analytical content of Schmitt's response to Thoma is fascinating. Schmitt, like Schumpeter, reduced political practice to a question of method. However, unlike Schumpeter, Schmitt did not take the concept of democracy as his object and redefine it as a method. Instead Schmitt posited democracy itself as a moral value and took liberal parliamentarism as an essentially disposable "method of government" and the object of his study and criticism (1926: 3).

Whereas I would suggest Schumpeter separated democracy (a political method) from parliamentary practice (the foundation on which the normative political ideals of German liberalism rested) in order to preserve the possibility of a modern liberal parliamentary democracy, Schmitt's argument is the inverse. Schmitt characterized liberal parliamentary practice as the political method, and rhetorically took democracy as his political ideal, in order to refute the political liberalism of his peers. He then used a purportedly Rousseauean ideal of democracy to intellectually legitimate a unique and

\footnotetext{
5 The direct translation of Thoma's title is "Of the Ideology of Parliamentarism and Dictatorship." Somewhat strangely the "and dictatorship" part of the title has been eliminated from the English translation of that article which is included at the end of Kennedy's Crisis of Parliamentary Democracy under the title "On the Ideology of Parliamentarism" (Kennedy 1988).
} 
disturbingly fascist set of conditions for democratic success, which included a demand for a homogenous demos. ${ }^{6}$ Notably Schumpeter's definition of democracy in Capitalism, Socialism and Democracy accepts the ideals of political freedom, and formal equality, and is grounded on a social theory that accepts the on-going, empirical fact of pluralism, and political competition within the demos. By contrast Schmitt's anti-parliamentary theory of democracy insisted that for democracy to truly exist within a polity there had to be a demos that was homogenous and unanimous. Essentially Schmitt proposed an exclusive form of nationalism that dangerously exceeded a normal liberal theory of partriotism, and polemically presented dictatorship and mass public collectivism as the salvation of democracy. ${ }^{7}$

To validate this social theory, which takes on a prescriptive, normative dimension in Schmitt's argument, Schmitt turned to older intellectual sources. He noted that according to Rousseau a "true" democratic state "only exists where the people are so homogenous that there is essentially unanimity" (1926: 13). And so to justify his fascist concept of democracy argument Schmitt asserted an interpretation of Rousseau's general, or common, will that is not simply based on the idea of political unity, but instead on a more highly elevated concept of social unanimity. Even more importantly for the purpose of my current argument, Schmitt insisted that this particular interpretation was premised on an "ancient, one can even say classical, definition" that returned Rousseau to his proper roots (1926: 14, emphasis added). Thus, by connecting Rousseau to a "classical" understanding of democracy, Schmitt used a particular democratic reading of Rousseau's

\footnotetext{
${ }^{6}$ Note that Schmitt does not use the word demos, but his references to ancient democracy essentially resuscitate this concept. I will use it below as it adds a layer of conceptual clarity to Schmitt's argument. ${ }^{7}$ Neumann notes that at this historical juncture this myth of collective renewal formed the basis of a generic theory of fascism (944: 43-46).
} 
ideas as a proxy to intellectually legitimate his argument for a homogenous and exclusionary fascist state.

Is it merely coincidence that Schmitt, who was a colleague of Schumpeter's at Bonn from 1925-1928, used the word "classical" to define a theory of democracy that corresponds rather closely with the theory Schumpeter later attributed to that name? An examination of intellectual history suggests not.

\section{Historical Evidence of a Connection}

There are grounds to believe Schumpeter was aware of the intellectual exchange between Schmitt and Thoma and had, in fact, read Schmitt's reply. Archival evidence indicates Schumpeter knew, and corresponded with Schmitt and with Thoma, who were both colleagues of his at Bonn (Schumpeter 1926 [2001a]: 133; Schumpeter 1932 [2001a]: 211-213; Scheuerman 1999: 321n55-58). Evidence indicates Schumpeter was directly aware of Thoma's critical review of Schmitt, as it was published in a volume of the Archiv für Sozialwissenschaften und Sozialpolitik [Archive for the Social Sciences and Social Policy] of which Schumpeter was an active editor at the time. Schumpeter was also likely familiar with Schmitt's reply. Archival evidence indicates that Schumpeter had an established social relationship with Schmitt by the time of Schmitt's reply to Thoma (on 16 March 1926 Schumpeter wrote to congratulate Schmitt on his second marriage; in a postcard dated 8 September 1927 Schumpeter apologized to Schmitt and his new bride for being unable to attend a social event to which they had invited him). 
Anecdotal evidence suggests Schumpeter and Schmitt shared rich intellectual exchanges, which Schmitt, in particular, recalled fondly. Indeed, in 1948 Schmitt reminisced about what a "great pleasure" it was to "discuss with [Schumpeter]" at Bonn during the 1920s (Schmitt 1948: 101). Schmitt also indicated how much he enjoyed knowing, in 1948, that Schumpeter's ability to provoke, or to incite debate, continued unabated (Schmitt 1948: 101). ${ }^{8}$ Schumpeter, for his part, seemed to reciprocate this intellectual affection by expressing admiration for Schmitt's work, although I think we have to be careful about our interpretation here. ${ }^{9}$ A rather formal letter Schumpeter wrote to Schmitt on November 23, 1926, reveals that Schumpeter, in his role as editor of the Archiv, wrote to encourage Schmitt to complete a version of his Concept of the Political for publication there, a task that was completed in the second half of 1927, in an edition of the journal that again bore Schumpeter's name as editor (Schumpeter 1926c [2000a]: 133; Schmitt 1927:1-33). In this letter of solicitation for Schmitt's article, Schumpeter "personally adds" his encouragement of the project, by telling Schmitt it is important that "no other author but you [meaning Schmitt] speaks to our readers about this set of problems" (Schumpeter 1926c [2000a]: 133). In a further postcard dated 8 September, 1927 it has been noted that Schumpeter told Schmitt how he "once again" found himself “admiring" Schmitt's articulation of his political thinking (as quoted in Scheuermann

\footnotetext{
8 "Doch ist es mir vielleicht gestattet, mich daran zu erfreuen nach langer Zeit dem Geist Joseph Schumpeters wieder zu begegnen und zu beobachten, daß seine Inzitament-Wirkung unvermindert anhält" (Schmitt 1948: 101).

${ }^{9}$ It may be useful to connect Schumpeter's treatment of Schmitt's work to the manifesto Weber set out for the Archiv in his 1904 essay "The 'Objectivity' of Knowledge in Social Science and Social Policy.” That essay advocated an ethos of 'objective' communication between scholars of different political persuasions, and meant the editors of the journal (as well as scholars working within a Weberian intellectual paradigm) thought it important to solicit articles and egnage in debates in which scholars of varying political views explained such views (or policy recommendations) by articulating relatively 'objective' explanations or reasons for their positions. This ethos enabled a space in which scholars with conflicting opinions might 'objectively' debate various propositions, but also respect the views or style of argumentation employed by a thinker even while disagreeing with that argument's conclusions.
} 
1999: 198). ${ }^{10}$ But does this profession of admiration mean that Schumpeter was in political agreement with Schmitt?

\section{Connecting Schmitt and Schumpeter in Current Scholarship}

In opposition to Plamenatz, and in contrast to the dominant acceptance that Schumpeter's classical doctrine of democracy is a straw man based on no existing intellectual theory, I suggest that Schumpeter's Classical Doctrine may, in fact, have a very real intellectual source in Carl Schmitt's work. But what implication, if any, does Schumpeter's established connection to Schmitt have on the way we read his work and interpret the normative commitments underlying Schumpeter's theory of democracy?

To date the few scholars who directly treat the relationship between Schumpeter and Schmitt have tried to turn it into the kiss of death for Schumpeter. These critical arguments function by using comparative analysis to highlight the conceptual similarities between the two men and condemn Schumpeter by association. For example, citing the seemingly reciprocal admiration shared between the two men, and the fact that they seemed to share an "extensive set" of "intellectual assumptions," Scheureman has suggested the "intellectual exchange with Schmitt at Bonn... helped cement Schumpeter's own anti-democratic proclivities" (1999: 200; 206). Although Scheuerman concedes that Schumpeter's theory is "normatively and institutionally superior to Schmitt's," and "hardly fascistic," his final word is that "Schumpeter may be only a few steps away from Schmitt's path” (1999: 204, 206).

\footnotetext{
${ }^{10}$ I have not yet managed to get to the archive to check this translation or examine the larger textual context of remarks made in this postcard.
} 
Gerry Mackie enhances Scheuerman's argument by accentuating the "strong parallels between [Schumpeter and Schmitt's] critiques of democracy," as well as the similarities between Schumpeter's analysis and that of other elite authoritarians and accused fascists such as Sorel and Pareto (Mackie 2009: 146). To a greater or lesser degree other scholars also draw on these similarities as a way of criticising Schumpeter's theory and placing it firmly within a canon of democracy that is elite and verges on authoritarianism (Bellamy 2000: 67-107; Bellamy 2004: 27; Green 2010: 140-177). The trouble, however, is that none of the critics who consider the conceptual or personal connection between Schumpeter and Schmitt have linked Schmitt's discussion of democracy to the Classical Doctrine Schumpeter criticizes. This is a significant gap in thinking about the intellectual relationship between the two men, for Schumpeter spent an entire chapter knocking down a model of democracy based on "classical” principles. I submit that if one recognizes a correspondence between the Classical Doctrine Schumpeter critiques and the Classical definition of democracy Schmitt presents, the differences between Schumpeter and Schmitt become far more important and apparent. Although the two men shared an intellectual paradigm, a similar set of background considerations, and even a friendship, the institutional relationships they advocated - and the grammars of democracy each generated — result in very different theories and political ideals. Just because both men come from the same milieu, it does not follow that either uncritically accepted all the other had to say. In fact points of disagreement between the two might be precisely why each regarded the other as a valuable resource. It follows from this logic that Schumpeter might consider Schmitt an important interlocutor 
precisely because Schmitt represented views from which Schumpeter was trying to distance himself.

The remainder of this paper engages in a comparative conceptual analysis of Schmitt and Schumpeter. It proposes that Schmitt dismissed liberalism under the guise of democracy, whereas Schumpeter sought to preserve moral and political liberalism within democracy. In response to those who sometimes wonder why the history of ideas matters, the analysis at hand demonstrates that how we view the debate between Schumpeter and Schmitt has important implications for the way we, as citizens and scholars, think about political thinking, as well as the way we practise democracy, and what is at stake in our conception of the political.

\section{Schmitt's Fascist Theory of Democracy}

As I have already noted, Schmitt drew on Rousseau to legitimate a concept of democratic homogeneity. In Schmitt's theory this concept of homogeneity was not just a standard attached to the concept of the state as a politically organized society or polity, but also an ideal towards which the moral, spiritual, and biological or racial character of the demos should be oriented. Homogeneity was a valued political principle, and Schmitt's concept of democracy was not simply based on the ideal of a homogenous demos but on a society in which there was no gap between the identity of representative and represented. According to Schmitt, authentic classical democracy did not simply mean homogeneity but also the unity and unanimity of a political community (1928: 239, $247,255,259,262,263) .{ }^{11}$ There was, however, a problem for anyone who wished to

\footnotetext{
${ }^{11}$ It is possible to argue that Schmitt, whose chief speciality was international law, simply meant to set out a modern theory of statehood within the formation of an international order. However, Schmitt's argument
} 
realize such a vision. The demos established by the constitution of Europe's modern republics was far from homogenous and the more inclusive decision-making and parliamentary practices embraced by those publics created greater heterogeneity, as well as greater political and social unrest within the populace (at least according to Schmitt). How could the kind of homogenous political demos Schmitt described (and potentially idealized) be made possible within existing states?

To solve for the intrusion of this glaring social fact Schmitt argued that in order for democracy to be meaningful, a modern democratic state could (and should) "exclude one part of those governed without ceasing to be a democracy" (1926: 9). Thus Schmitt's theory looked favourably on any strategy that would "make it possible for a democracy to govern a heterogeneous population without making them citizens, making them dependent upon a democratic state, and at the same time held apart from this state" (1926: 10). One had to meet the criteria of homogeneity to be accorded full citizenship in this politically elitist and oppressive state. Under this arrangement the criteria of homogeneity was not applied to a concept of the state as an organized society (polity), but to the character of the demos: namely those members of the state who were granted full citizenship.

Schmitt's concept of homogeneity was not based simply on shared economics or geography, an agreement about political method and rules of the democratic game, or the thin form of liberal proceduralism that defines the general contours of modern democratic citizenship. Rather, the content of his argument indicates homogeneity was to extend

occurs at the beginning of a book that discusses the institutional mechanisms of politics within a domestic system. As I have pointed out, Schmitt's essay was also drafted as a reply to Thoma, who criticized the illiberal political implications Schmitt's earlier arguments had within a state. Schmitt's concept of homogeneity was not simply attached to a concept of the state as an organized society (polity), but to the character of the populace as a political unit (demos). 
much deeper to include biological and racial, as well as moral and religious, factors. For example, Schmitt applauded dominions like the Australian Commonwealth that only took those immigrants who conformed to a notion of the "right type of settler" (1926: 9). Suggestively, the criterion that is to help identify "the right type of settler" in the Australian case is unmistakably racial: "Australian law excluded certain immigrants on racial grounds" (1926: 90n26). Bothered by the problem of the mixed state, Schmitt found a partial solution to heterogeneity in the Australian example, which explained how in order to "preserve the unity of their national life... a people can admit emigrants from alien races only if within a reasonable time frame they show a willingness and capacity to amalgamate ideally as well as racially with them" (1926: 90n26). One must therefore be of one's nation mind, body and soul. The homogeneity and unanimity Schmitt demanded was not simply political, but also moral, racial, and ideological. It was not a rational and contingent convergence of a peoples' wills in a modus vivendi, for Schmitt argued that even the "unanimous opinion of one hundred million private persons" is "neither the will of the people nor public opinion" (1926: 16). The homogeneity of the demos had to run even deeper; it required a sacred union of the individual with a public spirit or soul (Schmitt 1922; 1923b; Kennedy 1998: 93; Colliot-Thélène 1999: 143). ${ }^{12}$

Schmitt's reply to Thoma also reiterated opinions he had outlined in an earlier book, Political Romanticism (Schmitt 1919). Incidentally Schumpeter was also familiar with this work of Schmitt's, for he mentioned it by name in a 1926 piece of correspondence to his good friend Gustav Stolper, along with the assessment that Schmitt is a "worldly Jesuit, but a 'spiritual' person" (1926b [2000a]: 119). Schumpeter's

\footnotetext{
${ }^{12}$ The ideal of a theologically-derived political community bound by a power that is "supraparliamentary ... and suprademocratic," recurs throughout Schmitt's oeuvre (see Schmitt 1932b: 34; 1922; 1923/1926; $1928 ; 1932 a)$.
} 
qualified "but" in this instance was not intended to be complimentary. Perhaps this was because Schumpeter was uncomfortable with the fact that Schmitt's moral ideal of democratic unity led Schmitt to reject the liberal ideal of parliamentary democracy based on multiple parties that competed for power within an electoral system. Indeed, Schmitt was sceptical that the "liberal tradition of the past century" could effectively "shape the will of the people" and create the "homogeneity" that he thought modern democracy required (1926: 15-16). ${ }^{13}$ Rather, Schmitt reasoned, there was no need for representative institutions regulated by the norms of competition and opposition since "democracy is the identity of governed and governing" whereby "those who command" are identical with "those who obey" (1926: 15). In fact, Schmitt argued:

the will of the people can be expressed just as well and perhaps better by acclamation, through something taken for granted, an obvious unchallenged presence, than through the statistical apparatus... dictatorial and Caesaristic methods not only can produce the acclamation of the people but can also be a direct expression of democratic substance and power (1926: 16-17).

And so, in the name of democracy, Schmitt advocated eliminating competitive elections, and by association, the ethical political deliberation they engendered.

Even more alarmingly, Schmitt rebuffed the ideas of formal political freedom and equality that were precursors to the concept of universal human rights but not part of ancient democratic tradition. Again under the cover of democratic rhetoric, Schmitt discarded the language and concept of formal equality as "a liberal, not a democratic, idea;" in its place he proposed a concept of "substantial equality" based on democracy's classical forms (1926: 11). Unsurprisingly, "substantial equality" was only to be extended to the homogenous citizens of the demos $(1926: 12,13)$. As for heterogeneity, Schmitt

\footnotetext{
${ }^{13}$ Thus Schmitt's views easily aligned with those of Weimar's conservative revolutionary nationalists who defended German "völkisch Kultur against cosmopolitan Zivilisation." As Herf notes, "on the one side stood the Volk as a community of blood, race and cultural tradition. On the other side was the menace of... liberalism, commerce, materialism, parliament and political parties, and the Weimar Republic" (1984: 35).
} 
was explicit about the fate of non-citizens within the democratic state he imagined (and eventually sought to make legal). He argued that the coexistence of citizens and noncitizens within this state was possible, but the non-homogenous minorities were to be "completely or partially without rights" and "restricted from the exercise of political power" (1926: 10). Finally, Schmitt returned to Rousseau to lend intellectual legitimacy to his position about those individuals who were not members of the demos:

for Rousseau the word slave has an entirely consequential meaning attained in the construction of a democratic state; it signifies those who do not belong to the people, the unequal, the alien or noncitizen who is not helped by the fact that in abstracto he is a 'person,' the heterogeneous who does not participate in the general homogeneity[,] and is therefore rightly excluded from it" (1926: 13-14).

According to Schmitt's interpretation of Rousseau, then, if one is not part of the homogenous people one is "unequal," and "alien," or a "noncitizen" and one's status as a human being is incidental. Essentially Schmitt used Rousseau to effectively erase any of the liberal humanist qualms that might arise in pursuing the ideals of homogeneity, and to pave the way for establishing an illiberal, authoritarian, state.

Although Schumpeter has been accused of elitism by a host of contemporary scholars, it is Schmitt who demonstrates what real democratic elitism looked like within the European intellectual milieu at the time. In a theoretical sleight of hand, Schmitt inverted the idea of democracy as rule by the people to rule by the chosen people over the rest, whereby the mechanism of political selection is not free election governed by the principle of formal equality, but determined in advance by other aspects of one's identity. From this position it was only one step further to an even more aggressive and imperialist form of fascism, still under the rhetoric of democracy, for democracy, according to Schmitt, required "first homogeneity and second — if the need arises — elimination or eradication of heterogeneity" (1926: 9). Using the elite and exclusionary political 
arrangements Schmitt associated with his version of fascist democracy, Schmitt evaluated democracy as a moral imperative under which any manner of unsavoury political means might be justified.

\section{Reading Schumpeter Against Schmitt}

Given this reading of Schmitt, if Schumpeter can really be said to be only a few steps away from Schmitt's theory of democracy, the steps are rather large ones. Critics who argue otherwise make much out of the fact that in his opening chapter Schumpeter admits that "democracy can logically rest on exclusionary definitions of the populace based on race, ethnicity, and religion" and admits "a blurry line between democracy and authoritarianism" (Scheuerman 1999: 200; Medearis 2001: 124). But Schumpeter's chapter, entitled, "setting the problem" does just as advertised: it articulates the problem, namely that a multitude of moral and political arrangements might exist under the guise of democracy_-including those antithetical to liberalism. A more sensitive question to ask here is: to what end? Why does Schumpeter's discussion reduce democracy to a method and a political means as opposed to a value or moral end unto itself?

In Scheuerman's opinion Capitalism, Socialism and Democracy reformulates “an onerous tradition of Central European authoritarianism in order to make it more palatable to an American audience" (1999: 184, 206). But I think, rather, that Schumpeter warned of the danger of democratic dictatorship in order to defend against it. Schumpeter did this by separating democracy, as a political method, from the question of broader political ends, thus deploying an analytical strategy intended to guard against the subversion and erasure of moral discourse from the political order. The structure of Schumpeter's argument is diametrically opposite to the way Schmitt, in a sleight of hand, invoked the 
ideal of democracy to trump moral deliberation about political means. In fact, nowhere is Schumpeter's intellectual strategy of differentiating between means and ends, political method and moral value, more necessary and more useful than in engaging, and evaluating, Schmitt's work. Furthermore, positing Schmitt as one of Schumpeter's intellectual sources and adversaries also serves to illuminate some of the more esoteric and seemingly anti-democratic remarks Schumpeter makes.

At this point a clarifying comment is in order. By suggesting Schmitt as an intellectual source for the classical doctrine I do not mean to say that Schmitt was Schumpeter's sole target. Schumpeter also explicitly criticised a strand of utilitarian moral theory that was better known by his Anglo-American audiences. But Schumpeter also noted that once the untenable, hyper-rational theory of utilitarian rationalism is exposed as empirically inadequate, the root of both Schmittian and utilitarian social theories (at least those that existed during Schumpeter's day) demanded a shared faith and a morally unified demos that was dangerously exclusionary and intolerant of difference. Schumpeter's point was that it was possible to have a working parliamentary democracy and a stable democratic community across conditions of pluralism without having to resort to an ideal of homogeneity, or to a singular and reductive way of thinking about moral ends within the demos. In particular Schumpeter worried about any version of political democracy that relied on faith and religion, or a "semi-mystic entity endowed with a will of its own - that 'soul of the people' that the historical school of jurisprudence made so much of" $(1942: 252,265)$. This locution draws a line straight back to Weimar's intellectual debates, and to Schmitt who, I have just demonstrated, suggested just such a theory of the people. And so, one might infer, Schumpeter's worry 
was that the existing utilitarian social theory of his day, as well as the unsophisticated theories of representation on which they relied, fit all too easily with Schmitt's social theory, and might therefore lead to the danger of fascism.

Schumpeter spared his Anglo-American audience from the intellectual tangle associated with the German side of those debates. Yet he also set forth a criticism that might apply equally to German and American variants of religiously driven democratic patriotism. Indeed, Schumpeter was adamant about the danger of treating democracy as a moral edict instead of a political method. Specifically, Schumpeter registered a strong warning about what happens to the classical doctrine if one abandons the liberal humanist answer that equality be "morally and politically binding... because every man is by nature exactly like every other man," to instead ground equality inside an exclusionary religious doctrine or a semi-mystical theory of national community (1942: 265). Again, what Schumpeter writes against here echoes Schmitt's insistence that the status of a noncitizen "is not helped by the fact that in abstracto he is a "person"" (Schmitt 1926: 1314). If elevated into an "ideal," "part of an ideal scheme of things" or "transposed into the category of religion," he warned, "[the classical] doctrine - and in consequence the kind of democratic persuasion that is based on it—changes its very nature. There is no longer any need for logical scruples about the Common Good and Ultimate Values" (1942: 266, 265 emphasis added). While Schumpeter rejected the hyper-rationalism of the utilitarian ideal that the proper application of logic necessarily led to only one moral end, he equally rejected an irrational mysticism that eliminated rational discussion and public persuasion from political deliberation. 
By reading Schumpeter's theory of democracy through the preoccupations of the German émigré intelligentsia from which he came, and by considering Schmitt one of the intellectual sources driving Schumpeter's criticism of democracy's Classical Doctrine, one arrives at a new understanding of why Schumpeter so adamantly divorces democracy, as a method, from moral deliberation in Capitalism, Socialism, and Democracy. If democracy were instead taken as an ideal, then the distinction between political means and moral ends would be disconnected and deliberation and responsible political discernment would fall by the wayside. The result is moral negligence and a society in which any means - the more sinister forms of exclusion promised by Schmitt's theory of democracy under the auspice of purity and the 'eradication of heterogeneity'can be rhetorically justified by invoking democracy. Indeed, according to Schumpeter "while accepting postulates carrying large implications about equality and brotherliness," a citizen who sees democracy as an ideal and not simply a method "will be in a position also to accept, in all sincerity, almost any amount of deviation from them that his own behaviour or position may involve" (1942: 266). Democratically sanctioned warfare, unsavoury racial policies, and nationalist chauvinism all fit within the scope of these deviations.

Schumpeter was very clear about what would happen if the concept of democracy were to represent a sacred moral and political union, and unanimity, in a political community. Suddenly democracy is elevated to the status of object, and "may become a flag, a symbol of all a man holds dear, of everything that he loves about his nation whether rationally contingent to it or not" (1942: 266). If this occurs, then the idea of national loyalty no longer simply means "doing one's duty with the army" but implies 
"voting with the government" (never questioning or opposing it) and "entering into unions sacrées" (1942: 352). But this idea of loyalty without ethical opposition, Schumpeter insisted, was not what "defending one's country" should mean (1942: 352). Indeed, Schumpeter worried that it is precisely this kind of community that is created under the classical doctrine's conception of the common good. In such a community there can be no room for discussion or dissent, because "fundamental dissent is looked upon not merely as error but as sin; it elicits not merely logical counterargument but also moral indignation" (1942: 266). Schumpeter was also very clear where a hyper-rational common good or an irrational illogic of religiosity might lead within a state. To "exalt national unity into a moral precept," he admonished, "spells acceptance of one of the most important principles of fascism" (1942: 352n4).

The preceding account thus presents a new answer to the old question about Schumpeter's intellectual sources, and a deeper understanding about why it would have been important for Schumpeter to analytically define democracy as a method divorced from pre-ordained moral commitments. Indeed, I submit that Schumpeter engaged Schmitt's classical theory of democracy, and reformulated it in order to protect the practice of moral deliberation about political means and the ends to which political practice is directed. In doing so he also paved the way for a sharper version of liberal, and democratic, political theory.

\section{Bibliography}

Bachrach, Peter. 1967. The Theory of Democratic Elitism: A Critique. Boston: Little Brown.

Bellamy, Richard. 2000. Rethinking Liberalism. London: Pinter. 
_ 2004. "Developments in Pluralist and Elite Approaches." In The Blackwell Companion to Political Sociology edited by Kate Nash and Alan Scott. Oxford: Blackwell: 17-28.

Brito Viera, Monica and David Runciman. 2008. Representation. Cambridge: Polity.

Caldwell, Peter C. 2000. "Richard Thoma." In Weimar: A Jurisprudence of Crisis, edited by Arthur J. Jacobson and Bernhard Schlink. Berkley: University of California Press: 151-156.

—. 2008. "The Citizen and the Republic in Germany, 1918-1935." In Citizenship and National Identity in Twentieth-Century Germany, edited by Geoff Eley and Jan Palmowski. Palo Alto: Stanford University Press: 40-56.

Colliot-Thélène, Catherine. 1999. "Carl Schmitt versus Max Weber: Juridical Rationality and Economic Rationality." In The Challenge of Carl Schmitt, edited by Chantal Mouffe. London, Verso: 138-154.

Davis, Lane. 1964. "The Cost of Realism: Contemporary Restatements of Democracy." Western Politics Quarterly 17: 37-45.

Döring, Herbert. 1983. "Schumpeter's Britain - Forty Years On.” West European Politics $6(1): 5-22$.

Dyzenhaus, David. 1996. "Liberalism After the Fall: Schmitt, Rawls and the Problem of Justification." Philosophy and Social Criticism 22 (3): 9-37.

- 1997a. Legality and Legitimacy: Carl Schmitt, Hans Kelsen and Hermen Heller in Weimar. Oxford: Clarendon Press.

— 1997b. "Legal Theory in the Collapse of Weimar: Contemporary Lessons?" The American Political Science Review. 19 (1): 121-134.

Gottlieb, Manuel. 1959. "The Ideological Influence in Schumpeter's Thought." Zeitschrift für Nationalökonomie 19 (1-2): 1-42.

Green, Jeffery Edward. 2010a. The Eyes of the People: Democracy in an Age of Spectatorship. Oxford: Oxford University Press.

- 2010b. "Three Theses on Schumpeter: Response to Mackie." Political Theory 38: $268-275$.

Held, David. 2008. Models of Democracy. $3^{\text {rd }}$ ed. Cambridge: Polity Press. 
Herf, Jeffrey. 1984. Reactionary Modernism: Technology, Culture and Politics in Weimar and the Third Reich. Cambridge: Cambridge University Press.

Kelsen, Hans. 1926. Das Problem des Parlamentarismus. Vienna: Wilhelm Braumüller.

Kennedy, Ellen. 1988. Introduction to The Crisis of Parliamentary Democracy, by Carl Schmitt, translated by Ellen Kennedy. Cambridge MA: MIT Press: xiii-l.

Lichtman, Richard. 1969. "The Façade of Equality in Liberal Democratic Theory." Inquiry: An Interdisciplinary Journal of Philosophy 12 (1-4): 170-208.

Mackie, Gerry. 2009. “Schumpeter's Leadership Democracy.” Political Theory 37: 128153.

—. 2010. "Reply to Green.” Political Theory 38: 276-281.

März, Eduard. 1991. Joseph Schumpeter: Scholar, Teacher and Politician. New Haven: Yale University Press.

McCormick, John P. 2004. "Introduction: Identifying or Exploiting the Paradoxes of Constitutional Democracy? An Introduction to Carl Schmitt's Legality and Legitimacy." In Legality and Legitimacy, edited and translated by Jeffery Setizer. Durham NC: Duke University Press: xiii-xliii.

Medearis, John. 2001. Joseph Schumpeter's Two Theories of Democracy. Cambridge MA: Harvard University Press.

- 2009. Joseph A. Schumpeter. New York: Continuum.

Miller, David. 1983. “The Competitive Model of Democracy.” In Democratic Theory and Practice, edited by Graeme Duncan. Cambridge: Cambridge University Press: 133-155.

Mommsen, Wolfgang J. 1974. The Age of Bureaucracy: Perspectives on the Political Sociology of Max Weber. Oxford: Basil Blackwell.

Neumann, Franz Leopold. 1953. "The Social Sciences.” In The Cultural Migration: the European Scholar in America, edited by W. Rex Crawford. Philadelphia: University of Pennsylvania Press: 4-25.

Pateman Carole. 1970. Participation and Democratic Theory. Cambridge: Cambridge University Press.

Plamenatz, John P. 1973. Democracy and Illusion: An Examination of Certain Aspects of Modern Democratic Theory. London: Longman. 
Popper, Karl. 1962 [2011]. The Open Society and Its Enemies. London: Routledge Classics.

Posner, Richard. 2003. Law, Pragmatism, and Democracy. Cambridge MA: Harvard University Press.

Ricci, David M. 1970. "Democracy Attenuated: Schumpeter, the Process Theory, and American Democratic Thought.” Journal of Politics 32 (2): 239-267.

Rousseau, Jeans Jacques. 1762 [1997]. "Of the Social Contract.” In The Social Contract and Other Later Political Writings, edited by Victor Gourevitch. Cambridge: Cambridge University Press: 39-151.

Runciman, David. 2007. “The Paradox of Political Representation.” Journal of Political Philosophy. 15 (1): 93-114.

Santoro, Emilio. 1993. "Democratic Theory and Individual Autonomy: An Interpretation of Schumpeter's Doctrine of Democracy." European Journal of Political Research 23: 121-143.

Scheuerman, William E. 1993. "The Rule of Law Under Siege: Carl Schmitt and the Death of the Weimar Republic." History of Political Thought 14 (2): 265-280.

— 1995. "Is Parliamentarianism in Crisis? A Response to Carl Schmitt." Theory and Society 24 (1): 135-158.

— 1996. "Legal Indeterminacy and the Origins of Nazi Legal Thought: The Case of Carl Schmitt." History of Political Thought 17 (4): 571-590.

-1999. Carl Schmitt: End of the Law. Lanham MD: Rowman \& Littlefield.

Schmitt, Carl. 1919 [1986]. Political Romanticism. Translated by Guy Oakes Cambridge MA: MIT Press.

— 1922 [1985]. Political Theology: Four Chapters on the Theory of Sovereignty. Translated by George Schwab. Cambridge MA: MIT Press.

- 1923a [1988]. The Crisis of Parliamentary Democracy. Translated by Ellen Kennedy. Cambridge MA: MIT Press.

_. 1923b [1996]. Roman Catholicism and Political Forms. Translated by G. L. Ulmen. Westport CT: Greenwood Press.

1926 [1988]. "On the Contradiction between Parliamentarism and Democracy." Preface to The Crisis of Parliamentary Democracy. $2^{\text {nd }}$ ed., translated by Ellen Kennedy. Cambridge MA: MIT Press: 1-17. 
— 1927. "Der Begriff des Politischen." Archiv für Sozialwissenschaften und Sozialpolitik 58: 1-33.

—. 1928 [2008]. Constitutional Theory. Translated by Jeffery Seitzer. Durham NC: Duke University Press.

_ 1932a [1976]. The Concept of the Political. Translated by George Schwab. New Brunswick NJ: Rutgers University Press.

1932b [2004]. Legality and Legitimacy. Translated by Jeffery Seitzer. Durham NC: Duke University Press.

—. 1948 [1991]. Glossarium: Aufzeichnungen der Jahre 1947-1951. Herausgegeben von Eberhard Freiherr von Medem. Berlin: Duncker and Humblot.

Schmitter, Philippe, C. and Terry Lynn Karl. 1996. "What Democracy is ... and is Not." In The Global Resurgence of Democracy, edited by Larry Diamond and Marc F. Plattner. Baltimore: John Hopkins University Press: 49-62.

Schumpeter, Joseph A. 1926a. "Postcard to Carl Schmitt, 16 March 1926." In William Scheuerman, Carl Schmitt: End of the Law. Lanham: Rowman \& Littlefield 1999: 197.

1926b [2000a]. "An Gustav Solper, 1 August 1926.” In Joseph Alois Schumpeter, Briefe / Letters, edited by Ulrich Hedtke and Richard Swedberg. Tübingen: Mohr Siebeck: 117-120.

1926c [2000a]. "An Carl Schmitt, 23 November 1926.” In Joseph Alois Schumpeter, Briefe / Letters, edited by Ulrich Hedtke and Richard Swedberg. Tübingen: Mohr Siebeck: 133.

—. 1927. "Postcard to Carl Schmitt, 8 September 1927." In William Scheuerman, Carl Schmitt: End of the Law. Lanham MD: Rowman \& Littlefield 1999: 198.

_. 1942 [1975]. Capitalism, Socialism and Democracy. New York: Harper Perennial.

Schumpeter 1932 [2001a]. “An Richard E. Thoma, 31. März 1932.” In Joseph Alois Schumpeter, Briefe / Letters, edited by Ulrich Hedtke and Richard Swedberg. Tübingen: Mohr Siebeck: 211-213.

Shapiro, Ian. 2003. The State of Democratic Theory. Princeton: Princeton University Press. 
Shapiro, Ian and Casiano Hacker-Cordón, eds. 1999. Democracy's Value. Cambridge: Cambridge University Press.

Soutphommassane, Tim. 2011. "Danger in Toxic Discourse.” The Australian August 6 $<$ http://www.theaustralian.com.au/news/opinion/danger-in-toxic-discourse/storye6frg6zo-1226108840881> Accessed September 30, 2011.

Thoma, Richard. 1925. "'Zur Ideologic des Parlamentarismus und der Diktatur." Archiv für Sozialwissenschaften und Sozialpolitik 53: 212-217.

Thoma, Richard. 1925 [1988]. "On the Ideology of Parliamentarism.” In The Crisis of Parliamentary Democracy, translated by Ellen Kennedy. Cambridge MA: MIT Press, 1988: 77-83.

Walker, Jack L. 1966. "A Critique of the Elitist Theory of Democracy." American Political Science Review 60 (2): 285-95.

Weber, Max. 1904 [2004]. "The 'Objectivity' of Knowledge in Social Science and Social Policy." Translated by Keith Tribe. In The Essential Weber: A Reader, edited by Sam Whimster. London: Routledge: 359-404.

Wolfe, A. B. 1943. Review of Capitalism, Socialism and Democracy, by Joseph Schumpeter. Political Science Quarterly 58 (2): 265-267. 